\title{
ESCRITOR, AUTOR E LEITOR: \\ PRESENÇAS NO MUNDO DA LITERATURA
}

Por Marcos Bueno

ALMEIDA, L. P. de. Escrita e Leitura: a produção de subjetividade na experiência literária. Curitiba: Juruá, 2009.

\section{RESUMo}

O livro Escrita e Leitura faz uma análise da literatura resultante da tese nietzschiana da morte de Deus à luz da modernidade. Texto produzido com rigor, afirma que a literatura é uma forma de resistência e dominação aos mecanismos sutis de ordenação da linguagem. $O$ autor relata a análise da experiência literária e suas conexões com a produção da subjetividade na escrita e na leitura. Resgatando Foucault quando afirma que uma obra literária exige três presenças: do escritor que produz, do autor que publica e do leitor que interpreta o texto dentro de dupla subjetividade, do autor e do leitor.

Palavras-chave: escrita e leitura; subjetividade; experiência literária.

\section{WRITER, AUTHOR AND READER: \\ PRESENCE IN WORLD LITERATURE}

\begin{abstract}
The book Escrita e Leitura is a literature review of the resulting theory Nietzschean death of God in light of modernity. Text produced accurately states that literature is a form of resistance to domination and subtle mechanisms sort of language. The author reports the analysis of literary experience and its connection with the production of subjectivity in the writing and reading. Rescuing Foucault when he states that a literary work requires three appearances: the writer who produces, which publishes the author and the reader who interprets the text within double subjectivity, the author and the reader.
\end{abstract}

keywords: reading and writing; subjectivity; literary experience.

\footnotetext{
^ Psicólogo. Formação em Gestalt-terapia pelo NUP-GT,especializaçao em administração pública pela Fundação Getúlio Vargas, especilização em administração: criatividade, inovação e oportundiade de negócios pela Universidade Federal de Uberlândia/Université du Quebec, mestrado em engenharia de produção pela Universidade Federal de Santa Catarina, doutorando pela Pontifícia Universidade Católica de Goiás e professor da Universidade Federal de Goiás/Campus Catalão.

E-mail: mlbueno@gmail.com
} 
O livro de Leonardo Almeida apresenta como as letras costumam formar labirintos para que os olhos vejam e os significados das palavras construam formas aos sentidos propostos pelo autor. Labirintos como aqueles que represam a palavra para, só assim, a ouvirmos. Esculpida para representar o imaginário, uma escritura, desafia, seduz, convida todos os sentidos. Feito chave, intenciona a acessibilidade à alma, afinal, à nossa humanidade. Como adentrar e percorrer um labirinto assim, similar àquele que chamamos vida representada pelo imaginário dos escritores?

Escrita e Leitura, de Leonardo Almeida, é destaque entre as obras contemporâneas importantes no campo da literatura em seu entrelaçamento com a psicologia. Um texto produzido com rigor, resultado da tese de doutoramento de Leonardo Pinto de Almeida na Pontifícia Universidade Católica do Rio de Janeiro. Esse é o título de um texto que trata de um processo literário reflexivo. Escrever e ler, por sua vez, é um texto paradoxal. Provoca uma discussão do problema da experiência literária em sua relação com o tema sobre a morte de Deus na perspectiva nietzschiana na produção da subjetividade. Um debate sobre dar visibilidade ao invisível do imaginário do escritor que procura chegar ao leitor. O encontro da filosofia de Nietzsche com alguns pensadores franceses, citados pelo autor e cria espaços de reflexão inteiramente novos e inesperados.

$\mathrm{O}$ trabalho faz um percurso significativo no pensamento filosófico francês contemporâneo, atravessando as obras de Blanchot, Foucault, Barthes, Deleuze e Guattari à luz da escrita literária. $\mathrm{O}$ autor propõe que o ato de escrever constrói mundos. O livro está organizado em quatro capítulos: o primeiro aborda a literatura como uma escrita nas paragens da morte; o segundo versa sobre as figuras subjetivas do escritor e do autor, levando em conta a experiência total do escrever e a mitologia autoral; o terceiro trata das vicissitudes da leitura literária, assinalando sua importância como experiência total; e o quarto reflete sobre as capturas da experiência literária, feitas pelas práticas de interpretação, de unificação e de sistematização da literatura. Esse livro amplia a reflexão sobre o mundo subjetivo que gira em torno da literatura, por meio dessa perspectiva nietzschiana da morte de Deus na aurora da modernidade.

O texto é provocativo e procura evidenciar entre a palavra e o silêncio, a linguagem, o ser e o outro, a obra e seus impactos, o que faz da literatura um espaço de criação e de produção do imaginário, da subjetividade. A literatura é uma experiência singular, na qual a subjetividade se encontra numa condição incomum, do ser e da presença, da consciência e da verdade, da unidade e da totalidade. O próprio Freud afirmou que a psicologia e a psicanálise têm muito a aprender com a literatura e com os escritores.

O texto mostra um manejo hábil com a palavra que flui, permitindo e incentivando um debate profícuo e contínuo do início ao fim do livro. Cita Blanchot, entre outros nomes de destaque da literatura francesa, que afirma ser a literatura, um espaço de ressonância, um encontro entre o escritor, o texto e o leitor num grau zero da finitude humana. Indica também que estamos mergulhados no mundo da linguagem, que é por si um mundo paradoxal. Vivemos nela, com ela e por ela. 
Escritor e leitor se diluem e se misturam no decorrer do texto pela ressonância da palavra, onde o problema da experiência literária aponta para a emergência da criação e da morte numa perspectiva nietzschiana. O Prazer de ler esse texto está provavelmente entre as obras contemporâneas importantes no campo intersubjetivo da literatura e da psicologia. A obra não só pensa a literatura, mas também reflete sobre a produção de subjetividade na experiência literária. Por outro lado, tem o mérito de desvelar vários campos da realidade (a literatura, a filosofia, a política e psicologia), criando espaços de reflexão inteiramente novos, provocadores e inquietantes bem ao estilo de Nietzsche.

O texto de Almeida é uma obra singular e de destaque no campo da psicologia e da literatura. Poucos autores arriscam o enfrentamento da multidisciplinaridade, que é um aspecto de originalidade que beneficiará os leitores nesse espaço criativo literário, com a psicologia sob as lentes da subjetividade e com o rigor que o autor propõe no texto.

O primeiro pesquisador a publicar um livro sobre a interface psicologia e literatura no Brasil foi Dante Moreira Leite na década de 1950, professor emérito da Universidade de São Paulo. Somente agora surge um novo, renovado e ousado trabalho a abordar esse tema e com maior profundidade. Almeida parte de uma análise histórica da literatura que resulta da tese nietzschiana da morte de Deus à luz da modernidade.

Almeida constrói, então, o encontro entre a linguagem e o escritor que é abordado a partir do descentramento e da dissolução do eu que é parte integrante da literatura enquanto experiência totalizante, como desejava Blanchot. $\mathrm{O}$ autor propõe que como acontece na escrita, a prática da leitura também deve dar lugar a um processo de subjetivação para que se possa apreender a experiência literária na sua singularidade. A literatura como acontecimento histórico no processo de criação do escritor, dando à luz um mundo imaginário. Compreender o mundo por meio da leitura e da escrita é uma poderosa fonte de prazer e descobertas descritas pelo autor. A experiência com o texto, seja como escritor, seja como leitor, está sempre nos libertando de nós mesmos, da tradição, de Deus, da ordem, dos próprios nomes. Surge aí, no texto, a importância da transgressão. A criação é sempre um processo de libertação crítica e transgressiva.

$\mathrm{O}$ autor afirma estar diante de uma potência poética, assim como afirmou Aristóteles que a palavra tem potência. O texto tem um movimento provocativo às reflexões de Nietzsche, de Blanchot e de Foucault, que o autor denomina um cuidado de distinguir duas mortes. Surge a questão problematizadora do texto: De que morte falamos? De que maneira morremos?

Ao concluir, com bases em uma perspectiva política da linguagem, na experiência literária, ocorrem duas mortes: uma morte relacionada com a morte de Deus, colocando em evidência o tema da finitude em sua relação com a linguagem, assinalando a experiência de vazio deixado pelo fim da tradição e da ordem. 
E outra morte, que se reedita a cada ato da escrita literária quando a experiência impessoal, não individual, não autoral do escrever e do ler é ditada pela construção da intencionalidade da experiência. Assim, torna-se possível pensar na ligação entre a experiência literária, que é uma experiência singular da subjetividade, com os paradoxos da linguagem, já que a potência transgressora da literatura, a subjetividade é conduzida então a se constituir e perecer ao mesmo tempo.

Esta segunda morte assinalada por Almeida é aquela que faz aparecer um sujeito da ação da escrita ou um elemento subjetivo relativo à experiência literária. E conclui-se dizendo que a primeira morte é convocada; fazer morrer este autor para emergir um efeito-subjetividade diferente, impessoal, já que pode suportar a sua morte. Temos aí o que o autor busca nessas duas mortes, mas entre elas se percebe uma circularidade. O paradoxo do encontro. O paradoxo da experiência. A segunda morte parece ser a condição da repetição da primeira. Falar da morte na experiência literária é falar dessas duas mortes, uma de fundo ontológico e outra política, sendo as duas indissociáveis.

Leonardo Almeida conclui que na escrita e na leitura ocorre uma ação ética-político-filosófica que denomina de produção da subjetividade. O livro Escrita e Leitura talvez busque uma perspectiva compreensiva da realidade do sujeito que escreve e produz o texto e do sujeito que lê e interpreta através de seus desejos, os símbolos do escritor.

Recebido em: 04 de abril de 2012 Aceito em: 10 de abril de 2012 